\title{
Empowerment of the mothers of children in a pediatric intensive care unit
}

\author{
O empoderamento de mães de crianças numa unidade de terapia intensiva pediátrica \\ Empoderamiento de madres de niños internados en unidad de terapia intensiva pediátrica
}

\author{
Monique de Sales Norte Azevedo', Isabel Cristina dos Santos Oliveira', Tania Vignuda de Souza', \\ Juliana Rezende Montenegro Medeiros de Moraes', Elena Araujo Martinez", Beatriz da Silva Araújo' \\ ' Universidade Federal do Rio de Janeiro, Anna Nery School of Nursing. Rio de Janeiro, Brazil. \\ "Fundação Oswaldo Cruz, National Institute of Women, Child and Adolescent Health, \\ Intensive Care Unit. Rio de Janeiro, Brazil.
}

How to cite this article:

Azevedo MSN, Oliveira ICS, Souza TV, Moraes JRMM, Martinez EA, Araújo BS. Empowerment of the mothers of children in a pediatric intensive care unit. Rev Bras Enferm [Internet]. 2018;71(3):998-1006. DOI: http://dx.doi.

org/10.1590/0034-7167-2016-0689

Submission: 12-27-2016 Approval: 05-21-2017

\begin{abstract}
Objective: to analyze the process of empowerment of the mothers of children hospitalized in a pediatric intensive care unit (PICU) according to Cheryl H. Gibson's framework. Method: a qualitative study with a non-directive interview in groups was carried out with 14 mothers in the PICU of a pediatric teaching hospital in the state of Rio de Janeiro, whose data were submitted to thematic analysis. Results: all mothers underwent at least one phase of the process of empowerment. Some of them achieved the phase of participatory competence in the care for their children, being heard by the team and expressing their needs, opinions, and questions. Final considerations: attentive listening and information sharing with mothers is necessary, in order to provide essential support so that they undergo the process of empowerment, thus involving themselves in care and decision-making regarding their children.

Descriptors: Power; Pediatric Nursing; Mothers; Hospitalization; Pediatric Intensive Care Units.
\end{abstract}

\section{RESUMO}

Objetivo: analisar o processo de empoderamento de mães de crianças internadas numa Unidade de Terapia Intensiva Pediátrica (UTIP) à luz do referencial de Cheryl H. Gibson. Método: pesquisa qualitativa, com entrevista não diretiva, em grupo, de 14 mães de uma UTIP de um hospital universitário pediátrico do Rio de Janeiro, cujos dados foram submetidos à análise temática. Resultados: todas as mães passaram por, pelo menos, uma fase do processo de empoderamento. Parte delas atingiu a fase da competência participativa no cuidado ao filho, sendo ouvida pela equipe e manifestando suas necessidades, opiniões e questionamentos. Considerações finais: é necessário escuta atenta e compartilhamento de informações com as mães, de modo a proporcionar os subsídios essenciais para que passem pelo processo de empoderamento e, assim, envolvam-se nos cuidados e nas tomadas de decisão relacionadas a seus filhos.

Descritores: Empoderamento; Enfermagem Pediátrica; Mães; Hospitalização; Unidades de Terapia Intensiva Pediátrica.

\section{RESUMEN}

Objetivo: analizar el proceso de empoderamiento de madres de niños internados en una Unidad de Terapia Intensiva Pediátrica (UTIP) a la luz del referencial de Cheryl H. Gibson. Método: investigación cualitativa, con entrevista no directiva, en grupo, de 14 madres de una UTIP de hospital universitario pediátrico de Rio de Janeiro, cuyos datos fueron sometidos a análisis temático. Resultados: todas las madres pasaron, por, al menos, una fase del proceso de empoderamiento. Parte de ellas alcanzó la fase de la competencia participativa en el cuidado del niño, siendo oídas por el equipo y manifestando necesidades, opiniones y cuestionamientos. Consideraciones finales: es necesario escuchar atentamente y compartir la información con las madres, de manera de brindar las ayudas esenciales para que pasen por el proceso de empoderamiento y, así, involucrarse en la atención y en las tomas de decisiones relacionadas con sus hijos. Descriptores: Empoderamiento; Enfermería Pediátrica; Madres; Hospitalización; Unidades de Cuidado Intensivo Pediátrico.

\section{CORRESPONDING AUTHOR Monique de Sales Norte Azevedo E-mail: moniquenorte@hotmail.com.br}




\section{INTRODUCTION}

The hospitalization of children in the pediatric intensive care unit (PICU) is a traumatic process for them and their families. This is because there is a family reorganization so that one of the members, usually the mother, must be able to perform a new role due to modifications in the family routine. In this setting, mothers have to empower themselves to provide care for their children during illness ${ }^{(1)}$.

Studies point out that mothers are those who often accompany their children during hospitalization. With this, they renounce the rest of their family and their social lives, living only for the hospitalized child, and distancing themselves from home and other family members ${ }^{(2-3)}$. This happens because mothers, in the PICU, hope to protect their children from the unknown, psychological and physical suffering, pain, anguish, sadness and crying, invasive procedures and, especially, from family rupture, which is often inherent to this whole process ${ }^{(1)}$.

Therefore, in order to feel more participatory with regard to the care provided for their children in the PICU, most mothers try to get involved in the unit's routine, question the behaviors of the health team, and obtain information with the purpose of deepening their knowledge of the illness and the treatments available, in order to express their needs and their children's ${ }^{(3-4)}$.

Consequently, the sharing of information between healthcare professionals and mothers must be a priority matter in the daily routine of healthcare services, including the PICU. Mothers, when carrying out a critical reflection based on new information presented, may empower themselves through this new knowledge, thus acquiring autonomy in care and decision-making regarding their children, who find themselves in a situation of fragility and severity ${ }^{(5)}$.

Some factors may contribute to the empowerment of the mothers of children in pediatric intensive care, such as: information shared by healthcare professionals, which provides the development of bonds, facilitates a rapprochement between children and their companions, and keeps hope alive; supporting social networks, especially the family; and participation in the care for the children hospitalized(6).

Therefore, it is of utmost importance that healthcare professionals rebuild their practice, becoming more attentive, promoting the development of bonds, and establishing partnerships with mothers, as well as mobilizing supporting social networks ${ }^{(5)}$.

Based on this context, the present study adopted the theoretical framework of the process of empowerment described by Cheryl H. Gibson in a study carried out with mothers of chronically ill children. This framework was chosen because it enabled recognition, promotion, and improvement of the abilities of mothers to meet their personal needs and, consequently, their children's, acquiring strategies to control their lives ${ }^{(7)}$.

For Gibson, the process of empowerment occurs in four interdependent and overlapping phases, as follows: precondition; process; results; and consequences. In the "precondition" phase, commitment, bond, and maternal love motivate and support the process of empowerment, thus serving as elements for its beginning ${ }^{(7)}$.
The second phase, "process," is made up of the following four components: in the first component, mothers discover reality, seek information on their children's health, and assume responsibility for this care. In the second component, they critically reflect on the reality experienced, carry out changes in their lives, develop a feeling of personal power, acquire confidence in their knowledge and strengths to face the situation experienced. In the third component, assuming command, they advocate in favor of their children, interact with healthcare professionals and services, as well as persisting to meet their children's needs. In the fourth component, as a result of the mothers' confidence in their strengths, competences, and abilities, the sensation of power remains even during changes in circumstances ${ }^{(7)}$.

However, there is frustration in this process, a factor that seems to be a powerful force so that mothers discover reality, critically reflect on the situation experienced and, consequently, promote changes in their situation, keeping the feeling of personal power ${ }^{(7)}$.

In the third phase, "results," mothers acquire participatory competence, because they are empowered and have the ability to provide care. In the last phase, "consequences," they acquire new abilities after experiencing all phases of the process of empowerment $t^{(7)}$. Therefore, the factors that influence this process are associated with intrapersonal matters, such as each mother's implicit values; beliefs; willpower and motivation; previous experiences; and interpersonal matters such as social support ${ }^{(7)}$.

In the literature in the healthcare area, the theme of empowerment of mothers in the PICU was approached in studies by means of a program for the empowerment of parents entitled Creating Opportunities for Parent Empowerment (COPE). The objectives of these studies were, through the use of the program, to improve and promote the knowledge of mothers regarding the behavior of their children who are hospitalized in situations of severity in the PICU and also after their hospital discharge, as well as to encourage the participation of mothers in emotional and physical care for their children ${ }^{(8-10)}$.

It is worth mentioning that the literature presents a compilation of the concepts of empowerment associated with the healthcare area presented in an integrative review. In addition, the article approaches its dimensions and measuring instruments, and brings as a contribution a single concept of empowerment based on the analysis of most of the articles in this area ${ }^{(11)}$. Therefore, the present study becomes relevant due to the lack of scientific publications that specifically approach the identification of the process of empowerment of mothers within the PICU.

\section{OBJECTIVE}

To analyze the process of empowerment of mothers of children hospitalized in a pediatric intensive care unit (PICU), according to Cheryl H. Gibson's framework.

\section{METHOD}

\section{Ethical aspects}

The ethical and legal precepts of Resolution $466 / 12^{(12)}$ were observed in the elaboration of the informed consent form 
(ICF) signed by the participants. Field research was developed after approval of the project by the research ethics committee of the abovementioned institution.

\section{Study design}

This was a qualitative study ${ }^{(13)}$ carried out according to the theoretical framework of the process of empowerment described by Cheryl H. Gibson.

\section{Methodological procedures}

\section{Study setting}

The setting was the PICU of a teaching pediatric hospital in the city of Rio de Janeiro.

\section{Data source}

Data were collected by means of a non-directive interview in groups, along with a form characterizing mothers and children, which provided support for analysis of the process of empowerment.

In order to use the non-directive interview in groups, theoretical and practical knowledge must coordinate with the objectives of the study, which requires experience in identifying signs and evidence and interpreting the gestures and words of the individuals interviewed ${ }^{(14)}$.

The guiding themes of the interviews were: feelings of mothers/diagnosis of their children; search for information/illness (diagnosis and treatment); support (accompaniers, family, neighbors, and community); care/mothers' knowledge and abilities; care/wishes and needs of mothers; search by mothers/meeting the needs of their children; information from the healthcare team/situation of their children; relationship with the healthcare team/opinions and questions; understanding/health condition of their children; and involvement/activities (home tasks, care for other children, work/job, leisure). The guiding themes of the non-directive interview in groups were established based on assumptions of the theoretical framework, so that most aspects met all phases of the process of empowerment.

The participants in the study were 14 mothers of children hospitalized in the PICU, the setting of the study. The inclusion criterion was biological or adoptive mothers who were accompaniers of children, and the exclusion criterion was family members, except mothers, who were accompanying children during their hospitalization in the PICU. The participants were identified with alphanumeric codes from $M 1$ to M14. The choice of the participants is supported by the theoretical framework of the study, in which the development of the mother-child bond is what supports the beginning of the process of empowerment. Theoretical saturation was obtained from the point at which the incorporation of few new elements to the theoretical density obtained with the interviews was observed ${ }^{(15)}$.

\section{Data collection and organization}

Data collection occurred from June to July 2014. A nondirective interview in groups was carried out by the main author of the study, and the relationship between author and participants was established from a weekly meeting with the group of mothers in the PICU, which facilitated the approach to carry out interviews.

Four meetings were held for the development of the nondirective interview in groups, which ranged from 50 minutes to one hour and ten minutes. Each mother only participated in one group, as follows: three groups with three participants and one group with five participants, in which all mothers positioned themselves during the interviews. The participants were randomly chosen. Sometimes, the groups took a long time to be formed, due to the absence of new children hospitalized in the PICU. It is worth mentioning the specific characteristic of the unit, with a profile of children with severe health issues. Therefore, although it was possible to invite some mothers to participate in the interviews, their children died before they could participate in the study.

The environments chosen for the undertaking of the nondirective interview in groups were: the cardiology outpatient classroom, in addition to the medical and nursing coordination room of the PICU, which ensured the participants' privacy. When gathering each group, the informed consent form was read, with an explanation of its items. The themes were individually affixed to the wall and indicated for the group. It was explained that speeches on the themes should be free, without any order pre-established by the researcher. In general, a mother started talking randomly about a theme, which encouraged the others, and the dialogue was held without conflicts. All interviews were recorded through an MP3 digital device.

\section{Data analysis}

Thematic analysis ${ }^{(13)}$ of the interviews was carried out and the following categories emerged: the process of empowerment of mothers in the PICU: from precondition to going on; and results and consequences of the process of empowerment: knowledge of mothers and children's care in the PICU. It is worth mentioning that, in these two categories, all phases of the process of empowerment of mothers were included.

\section{RESULTS}

Of the 14 participants interviewed, nine were single, aged between 15 and 42 years, and had one to three children. Regarding education level, five mothers had complete high school and five had complete elementary school; two had incomplete high school and two had incomplete elementary school.

With regard to children's identification and hospitalization data, they were aged between two months and 12 years. Seven children had a diagnosis of chronic illness from the intrauterine phase up to two years old. Medical diagnoses of current hospitalizations in the PICU were due to respiratory problems in eight children.

The current hospital stay in the PICU ranged from five days to two months and three days. Nine children were hospitalized in the PICU for the first time. Regarding the number of hospitalizations in other PICUs, one child was hospitalized four times, another was hospitalized twice, and three were hospitalized once. With regard to the number of hospitalizations in 
the pediatric hospitalization unit of the hospital setting of the study, it is worth mentioning that two children were hospitalized more than 10 times.

\section{The process of empowerment of mothers in the PICU: from precondition to going on}

The precondition for the beginning of the process of empowerment was observed in the interviews with mothers:

I think that being a mother is to preserve, love, and care! (M9)

The first component of the process of empowerment, "discovering reality," became evident in the speeches of the participants. That is, at the time when children were admitted to the unit, mothers, when facing this new condition, suffer from the lack of information about procedures carried out with their children:

The child has just arrived... mothers usually are not allowed to enter, but I think that a doctor should talk to us: "Mother, we are doing this with your child." However, when we stay and have no information... They forget the mother out there, but they have no idea how her heart is. We don't relax until we see our child. (M1)

Regarding reactions due to the children's hospitalization present in the first component of the process, the mothers reported negative feelings during the period of hospitalization, such as pain, fear, sadness, despair, and nervousness, as identified in the speeches:

Knowing what is happening with the child is very hard... we also want care for our heart, which is very painful. The word "ICU" hurts very much. (M1)

I was afraid of taking care of my daughter... I am proud of taking care of my daughter... I was very sad... This hurts very much... I renounced everything to be with my daughter... I fell into despair... I cried, I screamed along the corridor and I was very nervous. (M13)

Frustration is a determining factor, in the sense that mothers can promote continuous cycles of critical reflection on the reality experienced. When coming across a frustrating experience in the PICU, it is possible that they start reflecting on the situation, advancing towards the next components of the process of empowerment, as shown in the following reports:

Talking about bath procedures, I think that mothers should not to leave at the bath time, because a mother needs to see how the body of her baby is. (M1)

I cried when I saw him with his head shaven, because I left him in a way and received him in another. (M9)

However, mothers highlighted the search for information given by the medical team. They sought responses to their doubts in an attempt to understand what was happening to their children, evidencing the passage through the second component-one of the process of empowerment-that is, "critical reflection":

The doctor said that G. is doing well, and I told him: "If she is doing well, why does she still have a fever? The time she is on [antibiotics]; she should be already well. Then, is she not responding to the medication? (M2)

She undertook it twice [X-ray] [...] I asked her: "So, doctor, what is the result?" She answered: "It is nothing. The same thing as before." Then, Doctor L arrived at night and I asked him: "Doctor L, did his X-ray from the morning show anything?" He answered: "Worsening bilateral pneumonia." Then I said: "How come the doctor from the morning shift said she had nothing and now she has something, if it is the same X-ray?" (M4)

In addition to the medical team, the mothers sought information from the nursing team, confirming the presence of this component of the process, as observed in the following interview:

Here in the PICU, when I have any doubt regarding my son's treatment, I look for a nurse, a technician, and I am promptly answered... Sometimes, I am wrong regarding something that is happening there, and then they explain it to me. (M7)

The search for information is directly associated with the knowledge that mothers acquire throughout their children's entire illness history. In the next phase of the process of empowerment, they start assuming command of care. The experience of mothers in advocating in favor of their children to meet their needs was evidenced in the interviews:

J. was tired, very tired. I fought with her [doctor] to use a nebulizer. The kid was almost dying! (M4)

The child still has a fever; he still has a problem. (M3)

In this context, the sharing of information acquired by mothers with others who are experiencing the same situation of hospitalization of their children in the PICU becomes an important tool so that they deal better with the situation experienced. The fourth component of the process of empowerment, "going on," shows that, in this stage, mothers have already gained confidence in their strengths and abilities, feeling secure to exchange experiences with other mothers, as shown in the following speech:

Every opportunity I have with other mothers... I also share this knowledge I acquired... knowledge I acquired here with everybody, with doctors and nurses. It was here in the ICU that I learned how to really take care of my child! (M7)

In the fourth component, "going on," mothers present positive reactions during hospitalization, even experiencing the severity of the clinical condition of their children, as shown in the following speeches:

Today, I can see he is improving; then we are able to soothe our heart. (M4) 
Empowerment of the mothers of children in a pediatric intensive care unit Azevedo MSN, Oliveira ICS, Souza TV, Moraes JRMM, Martinez EA, Araújo BS.

Within the ICU, even with my child in a severe condition, I started feeling calm. He started reacting very well, and my feeling changed from pain to calm. (M7)

Results and consequences of the process of empowerment: Knowledge of mothers and children's care in the PICU

The participants in the study evidenced participatory competence, typical of the result phase, when they reported participation in the care provided to their children in the PICU:

It is very important for mothers to be present at the bath time... we must know how the body of the child is. The way to approach: "Mother, could you wait outside? We have to undertake a procedure." I say: "What kind of procedure?" They say: "We will give him a bath." I say: "But I want to be there!' (M1)

I will touch him, kiss him, smell him, comb his hair, put perfume on him, change his diaper, do whatever I want!... If I think something has to be done this or that way, I talk to the person; "It is wrong. That is the right way to do it" (M4)

Although her participation was not allowed by the professionals, her wish to participate was evidenced in this phase:

I also get upset at seeing my daughter there, not be able to give her bath, comb her hair, change her diaper... I wish I could help a little, but that anxiety of wanting to put her in my arms, make her sleep, feed her... but because I am not allowed to do these things now, I will let them be in charge. (M8)

The search for new knowledge, in a movement for the acquisition of new abilities as a consequence of the process of empowerment, was also present:

During the hospitalization here in the ICU, the doctor already told me that he needed to undertake a surgery called tracheostomy... being fed through a probe [gastrostomy]... it would reduce the possibility of bronchoaspiration. I had to learn in the first hospitalization that, when I leave here, I will have to take care of my son. I learned how to aspirate with nurses, I even learned how to change a diaper! (M7)

The involvement of mothers in care in the PICU environment was described in the interview with one mother:

I think that the team includes mother, nurse, and doctor. The warmth of mothers is essential, and when a mother is removed from the place, it seems that a piece of the puzzle is removed. The pieces are mother, doctor, and nurse. (M1)

The interpersonal aspect of the process of empowerment was evidenced in the relationship between the mother and the healthcare team:

If they are treating our children well, it is like they are treating us well! It is already great for me if they arrive and say good morning to my son, happily! (M5)

I leave her because I trust. Care provided during the day is good; they are good. It is also good at night. (M10)
One of the factors that influences the process of empowerment is the belief of each mother. Therefore, spirituality was present in some speeches:

I can say that I received a special divine support from God. This is the first support I received since the beginning. (M7)

If it is better for her, so let it be. I believe in God that my daughter will get better! (M8)

The support from family members received by mothers during the hospitalization of their children in the PICU also influences the process of empowerment. This was described in the interviews:

My mother-in-law helps me... My husband comes... I have support, thanks to God! I have my aunt, my uncle, my son, my sisters. I have support from my family. (M4)

I have support from my whole family! My sister comes two, three [days]. She takes turns with me. My mother, sisters, brothers-in-law were there, my brother came... now my family is everything! (M13)

However, the lack of support was also present in the speeches of some mothers in the PICU, showing frustration, as described in the interviews:

In the first month, his father barely had contact with him. (M3)

It is very rare seeing my mother-in-law changing... because if you have to be alone all the time, you really have to be alone. (M5)

\section{DISCUSSION}

The study evidenced the phases of the process of empowerment experienced by mothers during their children's hospitalization in the PICU. All mothers underwent at least one phase of the process of empowerment. Some of them acquired participatory competence to provide care for their children; succeeded in being heard by the team; and expressed their needs, opinions, and questions; and the result of the process of empowerment is shown below: they are already empowered. The others were still experiencing the first phases of the process.

Therefore, the precondition for mothers to begin the process of empowerment is that they have developed love, a bond, commitment, and responsibility for their children, ensuring them the best possible care and treatment ${ }^{(7)}$. Consequently, the hospitalization of their children in the PICU is experienced with much affliction, because at first they feel impotent in the face of this situation ${ }^{(16)}$.

The admission of children to the PICU, the setting of the study, is very stressful for mothers, because at first they are not able to get information about the health condition of their children. According to a study that approaches the admission of children to intensive care, mothers want information about the child who was hospitalized in a severe health condition. 
However, they are not allowed to enter the unit until the clinical condition of the child has been stabilized.

The time they spent waiting for information is permeated with anguish, fear, and anxiety. In this respect, the first component of the process of empowerment, "discovering reality," is highlighted, in which concern regarding the health condition of their children is shown, and this is the emotional response described in this component $t^{(1,7)}$.

Mothers whose children are hospitalized in a PICU experience intense suffering, in which feelings such as guilt, fear, anguish, nervousness, helplessness, and anxiety arise $\mathrm{a}^{(1,17)}$. Therefore, the study evidenced the dissatisfaction of mothers regarding their absence during the undertaking of procedures in the PICU. This may be a frustrating factor and may lead them to experience the components of the process.

Corroborating these findings, the literature shows that, due to the fulfilment of strict routines imposed in the PICU, family members feel frustrated and angry when asked to be absent during the change of shifts, rounds, and procedures. They end up not understanding why they have to be excluded, without sharing information, and also without explanation of the reasons for this procedure ${ }^{(18)}$.

Due to this reality, frustration is a determinant factor for mothers to experience the second component of the process of empowerment. Based on the experience related to the severity of the condition of the children hospitalized, some mothers in the study were able to critically reflect on this situation and, in the attempt to minimize doubts and uncertainties, they proactively participated in the search for information regarding their children's health with the professionals, showing concern for meeting their children's needs. This highlights the second component of the process of empowerment, "critical reflection"(7).

In this context, studies point out that the interaction between healthcare professionals and family is weakened when there is no effective communication between them. When a child is hospitalized, there is a greater need for information on the part of the family, to clarify any doubt regarding the clinical condition of the child ${ }^{(19-20)}$.

Therefore, during the hospitalization of their children, mothers start associating the symptoms presented with the clinical condition of their children. Based on the knowledge acquired during the child's entire illness history, they are able to express opinions and ask questions of the healthcare team regarding the needs of the child who is in critical condition, thus assuming command of the situation. With this, the third component of the process of empowerment stands out ${ }^{(7)}$.

The sharing of information must be directly associated with the care practice of the team, because parents need to have knowledge of the health situation of their children in order to minimize the fear and insecurity associated with their critical condition. Therefore, the development of strategies by healthcare teams is of utmost importance so that parents are more involved in care processes for the child hospitalized in the PICU $3,19,21-22)$.

For this purpose, dialogue between nursing teams and families must be established, not only to meet families' needs for information and questions, but to value their opinions in search of a comprehensive and individualized care $^{(23)}$.
In addition to the sharing of information between healthcare teams and mothers, the sharing of experiences among mothers with regard to their children's health condition must also be highlighted. The mothers who achieved the fourth component of the process of empowerment felt confident in providing care for their own children and wished to share the experiences acquired. These aspects made them critically reflect on the situation experienced, seek information from the healthcare team, become knowledgeable about the dynamics of the situation they were experiencing and, based on this, share information with other mothers who were going through the process of hospitalization of their children ${ }^{(7)}$.

Findings of the literature show that, within the PICU environment, mothers form a network in which they exchange and share experiences, and they are in solidarity with each other. Therefore, they understand that the exchange of experiences between them and other accompaniers, healthcare professionals, and the children themselves can make them feel strengthened during hospitalization, and thus able to adapt themselves better to the situation experienced ${ }^{(5,24)}$.

When mothers feel cared for and confident about the improvement in the clinical condition of their children, they start expressing positive reactions during the hospitalization of the child in the PICU. In spite of its being an environment associated with suffering and pain, the good evolution of the clinical condition of their children is a motivating factor for mothers to observe the hospitalization of their children in a different way, and allow themselves to think about this process in an optimistic way. Still in the fourth component of the process of empowerment, they are able to quickly adapt themselves to new situations that emerge throughout the entire history of the hospitalization of the child. Consequently, they acquire strength to continue on this path ${ }^{(7)}$.

In this context, families who are going through the process of empowerment and experiencing the hospitalization of their children are able to extract positive experiences regarding the improvement of the clinical condition of their children from this environment, in order to accompany their children during hospitalization and the efforts of the healthcare team to achieve improvement in their clinical condition ${ }^{(24)}$.

The phase of result of the process of empowerment is characterized by the acquisition of participatory competence by mothers, in which they are already empowered. Mothers must have developed a sound knowledge of their children's condition in order to achieve participatory competence. In addition, they must participate in care, have competence in decisionmaking, and have developed confidence in expressing what is best for their children ${ }^{(7)}$.

In the PICU, the setting of the study, mothers participated in the care provided for their children in several ways, such as body hygiene and changing of diapers and bedding. This may provide feelings of joy, security, and peace. With participation in care and consequent rapprochement of the healthcare team, it is believed that mothers are able to be heard by the team, because they express wishes, needs, opinions, and questions, and thus have a feeling of power.

In this respect, studies point to the fact that the participation of mothers in the care of their children in the PICU must 
be encouraged by healthcare teams, because they feel more included in the context of the unit, thus minimizing their anguish and generating a greater autonomy. Therefore, simple gestures of care provided for the children are quite significant for them, because they know they may somehow contribute towards their recovery ${ }^{(1,7)}$.

The participation of parents in the care for their children in an active and elucidative way, and in accordance with healthcare professionals, predisposes to an individualized care based on family as the promotor of decision-making. This type of care provided brings benefits for the binomial ${ }^{(25)}$.

However, the non-participation of mothers in the care for their children was present in the speeches. Therefore, it was evidenced in the literature that the exclusion of families in the care provided for their children hinders the recognition of their role during the child's hospitalization, making them more vulnerable in the intensive care environment. There is no integration between family and healthcare professionals, culminating in dissatisfaction and irritation with the healthcare service ${ }^{(26)}$.

The vulnerability of families in intensive care units becomes evident. This is present in the distance between healthcare teams and families, when families' needs for information are not completely met, and when there is a conflicting relationship between professionals and families, thus encouraging families to seek autonomy when facing their children's hospitalization in the PICU. Some of them prefer to accept the norms and routines established by the unit and subject themselves to this, in order to avoid hindering the work of the team ${ }^{(1,4)}$.

Therefore, it is of utmost importance that healthcare professionals value the approach based on family. Consequently, families must assume a more active attitude in the care process, overcoming the limitations resulting from healthcare services. Sharing care and decisions with families is necessary to change approaches based on children and pathology; thus, operationalization of care based on family is a challenge from the structural, ideological, and daily practice point of view of healthcare professionals $\mathrm{s}^{(1)}$.

The consequences of the process of empowerment of mothers can be evidenced from the time they are empowered in the care for their children. In this stage, mothers acquire new abilities, feel stronger and more efficient in resolving problems, acquire mastery with regard to the situation they experience in the intensive care environment, give new meaning to their experiences, and transforms their lives ${ }^{(7)}$.

Parents, when acquiring knowledge about their children's entire health history and the way of providing them care, may establish a relationship with healthcare professionals, sharing responsibility for the clinical condition of their children, and thus becoming essential in the provision of this care. Dialogue between teams and families must always be prioritized and both opinions must be valued, with the aim of comprehensive care for children ${ }^{(19,27)}$.

In this respect, the fact of mothers being heard is part of the relational or interpersonal aspect of empowerment. Therefore, mothers realize that professionals identify their knowledge about their children, in addition to being responsive and receptive to their speeches. The good relationship with the team allows mothers to establish a partnership with the healthcare team, with the aim of an open and respectful communication, as well as common commitments and objectives. Harmonious and cooperative coexistence between healthcare professionals and mothers favors the empowerment of some mothers in the $\mathrm{PICU}^{(7)}$.

The interaction of family members with healthcare teams is beneficial. By means of small gestures, friendly talk, and dialogue, families establish a good relationship with healthcare professionals and feel valued in the performance of their roles as children's caregivers ${ }^{(24)}$.

One of the aspects that influenced the process of empowerment was spirituality, which was presented as a driving force to give these mothers strength in the face of the reality experienced. They believed that God could be a support source, and this belief helped them to better deal with the hospitalization of their children in the $\mathrm{PICU}^{(7)}$.

Faith is an important ally in the fight of families for better health conditions for their children. It provides a greater emotional and sentimental control, as well as hope for their children's recovery. Therefore, families seek the necessary balance to experience this very difficult time, maximizing their confidence in the complete recovery of their children ${ }^{(1,26,28)}$.

Social support is another factor that influenced the process of empowerment and was essential, so that the mothers interviewed knew they could count on family members as a way of strengthening them to face this reality of suffering and uncertainties. Consequently, they felt encouraged to fight for their children's better health conditions ${ }^{(7)}$.

Social support from families becomes an important ally for mothers whose children are hospitalized in the PICU. Affectivity and bonds link these family members to overcome obstacles imposed by the hospitalization of children. Therefore, alliance and strengthening of affective bonds may be promoters of behaviors with the aim of the recovery of children in the $\mathrm{PICU}$ and reduction in vulnerability ${ }^{(5)}$.

However, the lack of support on the part of families, husbands, and children's parents was evidenced in the speeches of mothers in the study. The literature points out that they experienced feelings of loneliness while accompanying their children who were hospitalized in the PICU. In this respect, they wished to be able to count on the presence of their husbands and other family members, which did not happen often, thus causing them fear and uncertainties in the face of severity of their children's conditions ${ }^{(5,28)}$.

\section{Study limitations}

Limitations related to the results found in the present study are associated with specific characteristics of the setting of the study and participants. That is, the unit had a profile of children with rare chronic and genetic illnesses, leading to a high severity condition and low turnover, because the hospital did not have a semi-intensive unit to admit children from the PICU. Therefore, the results cannot be generalized.

Contributions to the nursing, health, or public policy area

The results of the present study are expected to contribute to nursing care practice in evidencing the process of 
empowerment of mothers and their personal needs during the hospitalization of their children in the PICU.

The study evidenced that healthcare teams must provide these mothers with spaces for listening, as well as the possibility of development of a Singular Therapy Project ${ }^{(29)}$. Listening to mothers is an essential condition to provide comprehensive care for children and, due to this, meetings held by a multidisciplinary team within the PICU may promote effective exchanges between professionals and companions.

\section{FINAL CONSIDERATIONS}

In the interviews with mothers, the four phases of the process of empowerment were identified. At the time of data collection, each mother was experiencing one phase of the process. Some mothers of chronically ill children achieved participatory competence as a result of this process. In this phase, it can be said that they are already empowered.

The sharing of information between healthcare teams and mothers enabled each one to develop their own knowledge based on their experiences, beliefs, values, and ways of acting. Difficulties and changes of circumstances found by mothers during their children's entire history of illness also enabled empowerment. Therefore, it is important to highlight that empowerment is acquired by mothers in a procedural way.

Those who participated in the care provided for their children were able to express their opinions and used their knowledge to help their children. They tried to be heard by the healthcare team, because they understood that they had more detailed knowledge about their children.

However, when mothers were not involved in care, they could not recognize their role in the unit, which hindered the interaction with the healthcare team and, consequently, this factor negatively interfered with their process of empowerment.

Therefore, a change in the conduct of healthcare teams with regard to mothers of children in the PICU becomes necessary, by means of attentive listening and sharing of information. This attitude may provide necessary support so that these mothers undergo the process of empowerment, become involved in care, and participate in decision-making at the time of hospitalization of their children.

Further studies approaching the theme of empowerment are recommended, based on the same theoretical framework and from the point of view of other mothers and in other settings, so that nursing care practice meets the needs of mothers of hospitalized children.

\section{REFERENCES}

1. Santos LM, Oliveira VM, Santana RCB, Fonseca MCC, Neves ES, Santos MCS. Maternal experiences in the Pediatric Intensive Care Unit. Rev Pesq: Cuid Fundam[Internet]. 2013[cited 2016 Oct 31];5(1):3432-42. Available from: http://www.seer.unirio.br/index. php/cuidadofundamental/article/view/1992/pdf_703

2. Souza MA, Melo LL. Being a mother of child hospitalized with a chronic illness. Rev Min Enferm [Internet]. 2013 [cited 2016 Nov 12];17(2):362-67. Available from: http://www.reme.org.br/artigo/detalhes/655

3. Marques CDC, Lima MF, Malaquias TSM, Waidman MAP, Higarashi IH. Family caregivers of hospitalized child through nursing team view. Cienc Cuid Saude [Internet]. 2014 [cited 2017 Mar 31];13(3):541-8. Available from: http://www.periodicos.uem.br/ ojs/index.php/CiencCuidSaude/article/viewFile/22133/pdf_227

4. Xavier DM, Gomes GC, Barlem ELD, Erdmann AL. The family revealing itself as a being of rights during hospitalization of the child. Rev Bras Enferm [Internet]. 2013 [cited 2016 Nov 10];66(6):866-72. Available from: http://www.scielo.br/pdf/reben/ v66n6/09.pdf

5. Molina RCM , Higarashi IH, Marcon SS. Importance attributed to the social support network by mothers with children in an intensive care unit. Esc Anna Nery Rev Enferm[Internet]. 2014[cited 2016 Nov 20];18(1):60-67. Available from: http://www.scielo. $\mathrm{br} / \mathrm{pdf} / \mathrm{ean} / \mathrm{v} 18 \mathrm{n} 1 / 1414-8145$-ean-18-01-0060.pdf

6. Whalin I, EK AC, Idvall E. Empowerment from the perspective of next of kin in intensive care. J. Clin. Nurs [Internet]. 2009[cited 2014 Sep 15];18(18):2580-7. Available from: https://www.ncbi.nlm.nih.gov/pubmed/19538566

7. Gibson $\mathrm{CH}$. The process of empowerment in mothers of chronically ill children. J Adv Nurs [Internet]. 1995 [cited 2013 Apr 13];21:1201-10. Available from: http://onlinelibrary.wiley.com/doi/10.1046/j.1365-2648.1995.21061201.x/full

8. Roets L, Rowe-Rowe N, Nel R. Family-centered care in the paediatric intensive care unit. J Nurs Manag[Internet]. 2012 [cited 2017 Apr 29];20(5):624-30. Available from: http://onlinelibrary-wiley.ez29.periodicos.capes.gov.br/doi/10.1111/j.1365-2834.2012.01365.x/full

9. Melnyk BM, Alpert-Gillis L, Feinstein NF, Crean NF, Johnson J, Fairbanks E, et al. Creating opportunities for parent empowerment: program effects on the mental health/coping outcomes of critically ill young children and their mothers. Pediatrics [Internet]. 2004 [cited 2017 Apr 28];113(6):e597-e607. Available from: http://www.pediatrics.org/cgi/content/full/113/6/e597

10. Melnyk BM, Crean HF, Feinstein NF, Fairbanks E, Alpert-Gillis LJ. Testing the theoretical framework of the COPE Program for mothers of critically ill children: an integrative model of young children's post-hospital adjustment behaviors. J Ped Psychol[Internet]. 2007[cited 2017 Apr 30];32(4):463-74. Available from: http://dx.doi.org/10.1093/jpepsy/jsl033

11. Cerezo PG, Juvé-Udina ME, Delgado-Hito P. Concepts and measures of patient empowerment: a comprehensive review. Rev Esc Enferm USP [Internet]. 2016 [cited 2016 Nov 23];50(4):664-71. Available from: http://dx.doi.org/10.1590/S0080-623420160000500018 
12. Brasil. Ministério da Saúde. Resolução n. 466, de 12 de dezembro de 2012. Dispõe sobre as diretrizes e normas regulamentadoras de pesquisas envolvendo seres humanos. Diário Oficial da União de 2013, Seção 1.

13. Minayo MCS. O desafio do conhecimento: pesquisa qualitativa em saúde. 13 ed. São Paulo: Hucitec, 2013.

14. Hoffmann MV, Oliveira ICS. Non-directive interview: a possibility of group approach. Rev Bras Enferm [Internet]. 2009 [cited 2013 Jan 22];62(6):923-27. Available from: http://www.scielo.br/pdf/reben/v62n6/a21v62n6.pdf

15. Fontanella BJB, Luchesi BM, Saidel MGB, Ricas J, Turato ER, Melo DG. Sampling in qualitative research: a proposal for procedures to detect theoretical saturation. Cad Saúde Pública [Internet]. 2011 [cited 2014 Dec 07];27:389-94. Available from: http://www. scielo.br/pdf/csp/v27n2/20.pdf

16. Bosque AR. Participación familiar en una unidad de cuidados intensivos pediátricos: opinión de enfermería. Rev Enferm CyL [Internet]. 2013 [cited 2016 Nov 15];5(2):59-66. Available from: http:/www.revistaenfermeriacyl.com/index.php/revistaenfermeriacyl/article/ viewFile/88/79

17. Alves MVMFF, Cordeiro JG, Luppi CHB, Nitsche MJT, Olbrich SRLR. Experience of family members as a result of children's hospitalization at the Intensive Care Unit. Invest Educ Enferm [Internet]. 2013 [cited 2016 Oct 10];31(2). Available from: http:// www.scielo.org.co/pdf/iee/v31n2/v31n2a04.pdf

18. Silva T, Wegner W, Pedro ENR. Safety of pediatric intensive care inpatients: understanding adverse events from the companion's perspective. Rev Eletr Enf[Internet]. 2012[cited 2013 Apr 30];14(2):337-44. Available from: https://www.fen.ufg.br/fen_revista/ v14/n2/v14n2a14.htm

19. Rodrigues PF, Amador DD, Silva KL, Reichert APS, Collet N. Interaction between the nursing staff and family from the family's perspective. Esc Anna Nery Rev Enferm[Internet]. 2013 [cited 2017 Apr 02];17(4):781-7. Available from: http://www.scielo.br/pdf/ ean/v17n4/1414-8145-ean-17-04-0781.pdf

20. Figueiredo SV, Gomes ILV, Pennafort VPS, Monteiro ARM, Figueiredo JV. Therapeutic communication between health professionals and mothers accompanying children during inpatient treatment. Esc Anna Nery Rev Enferm [Internet]. 2013 [cited 2017 Apr 02];17(4):690-7. Available from: http://www.scielo.br/pdf/ean/v17n4/1414-8145-ean-17-04-0690.pdf

21. Engström A, Dicksson E, Contreras P. The desire of parents to be involved and present [Internet]. British Association of Critical Care Nurses [Internet]. 2015[cited 2017 Apr 02];20(6):322-30. Available from: http://onlinelibrary-wiley-com.ez29.periodicos. capes.gov.br/doi/10.1111/nicc.12103/full

22. Czulada L, Leino P, Willis TS. Partnering with a family advisor to improve communication in a Pediatric Intensive Care Unit. Am J Med Qual[Internet]. 2016 [cited 2016 Nov 13];31(6):520-25. Available from: http://ajm.sagepub.com.ez29.periodicos.capes. gov.br/content/31/6/520.full.pdf + html

23. Rodrigues PF, Amador DD, Silva KL, Reichert APS, Collet N. Interaction between the nursing staff and family from the family's perspective. Esc Anna Nery Rev Enferm [Internet]. 2013 [cited 2014 Jun 23];17(4):781-87. Available from: http://www.scielo.br/ pdf/ean/v17n4/en_1414-8145-ean-17-04-0781.pdf

24. Gomes GC, Oliveira PK. Family experience in the hospital during child hospitalization. Rev Gaúcha Enferm [Internet]. 2012 [cited 2014 May 10];33(4):165-71. Available from: http://www.scielo.br/pdf/rgenf/v33n4/en_21.pdf

25. Melo EMOP, Ferreira PL, Lima RAG, Mello DF. The involvement of parents in the healthcare provided to hospitalized children. Rev Latino-Am Enfermagem [Internet]. 2014[cited 2014 Nov 20];22(3):432-39. Available from: http://www.scielo.br/pdf/rlae/ v22n3/0104-1169-rlae-22-03-00432.pdf

26. Valderrama ML, Muñoz L. Needs of parents in caring for their children in a Pediatric Intensive Care Unit. Invest Educ Enferm [Internet]. 2016 [cited 2016 Oct 15];34(1):29-37. Available from: http://www.scielo.org.co/pdf/iee/v34n1/v34n1a04.pdf

27. Duarte MLC, Zanini LN, Nedel MNB. The daily routine of parents of children hospitalized with cancer: nursing challenges. Rev Gaúcha Enferm [Internet]. 2012 [cited 2013 Oct 03];33(3):111-18. Available from: http://www.scielo.br/pdf/rgenf/v33n3/15.pdf

28. Oliveira K, Veronez M, Higarashi IH, Corrêa DAM. Family life experience in the process of birth and hospitalization of a child in a neonatal ICU. Esc Anna Nery Rev Enferm [Internet]. 2013 [cited 2016 Dec 03];17(1):46-53. Available from: http://www.scielo. br/pdf/ean/v17n1/07.pdf

29. Luccia DD, Freitas CCS, Di Ribeiro DL, Saccani LP, Braga MB, Valle SHA. O protagonismo no Projeto Terapêutico Singular: singularidade e implicação do sujeito no nível terciário em saúde. A Peste [Internet]. 2015 [cited 2017 Apr 03];7(1):49-64. Available from: https://revistas.pucsp.br//index.php/apeste/article/viewFile/30464/21075 